condition. The lens was found to be present, its anterior surface being sprinkled with numerous fine white spots, some of them glistening almost like cholesterin crystals, and with the narrow beam it was found that this was the only lens opacity present, the rest of the lens having a uniform degree of relucency without the usual zones of discontinuity. The anterior face of the lens instead of being convex was flat, and it was further back from the plane of the iris than in the normal eye. The posterior surface of the lens had apparently its normal curve, the net result being that the lens seemed to have lost about one-third of its antero-posterior thickness.

The vitreous contained the usual lace-like membranes, and a distinct dark interval intervened between the posterior surface of the lens and a definite membrane, which one might describe as the hyaloid membrane.

The only explanation I can suggest for what has occurred in this case is that the opacity in the lens of the right eye was entirely confined to the anterior cortex, and that the opaque lens matter underwent absorption. This would account for the flattening and recession of the anterior surface of the lens, and the absence of any apparent change in the other parts of the lens.

Dr. Barrie, with whom I discussed the case, kindly consulted his notes, and was able to confirm the patient's statement that at the date when he saw her she had a mature cataract in the right eye. Although operation had been proposed nothing was done.

\title{
A CASE OF SEPTIC FOCUS IN THE RETINA OF AN APPARENTLY HEALTHY BOY AGED I5 YEARS
}

BY

\section{K. WALler TODD}

LATE HOUSE SURGEON, OPHTHALMIC DEPARTMENT, LONDON HOSPITAL

ON August 27, 1924, W. W., a somewhat obese Hebrew boy, aged 15 years, attended the Out-Patient Department for loss of vision of the right eye; this he had first noticed on waking the same morning. He was admitted for observation under $\mathrm{Mr}$. Charles Goulden, who has kindly given permission for the case to be published.

Routine examination revealed vision reduced to ability to count fingers at three feet distance, and nothing abnormal in the media. The fundus picture is shown in the accompanying painting by Messrs. Theodore Hamblin, to whom I am indebted for the favour of a black and white print for publication. The painting 
was made on the 28th, the picture not having materially changed in twenty-four hours. The congestion of the veins was even more evident than is represented. It is of considerable interest in view of the literature on the subject that the condition was mistaken for thrombosis of the central vein. Absence of peripheral haemorrhages is strongly against this diagnosis. It may further be

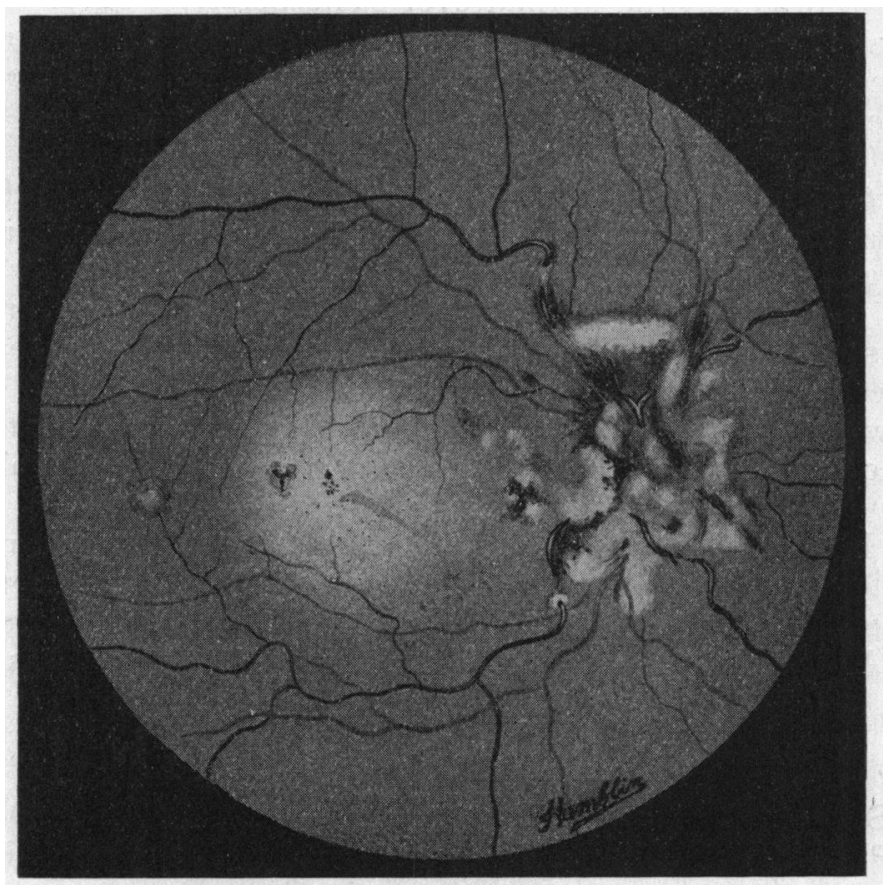

remarked that the youngest case of primary thrombosis found in the literature by Foster Moore ${ }^{(4)}$ was aged 30 years.

No cause was found for the condition. A history has since been obtained that the boy had had a cold in the head, associated with some headache, during the week previous to admission. An exhaustive clinical examination revealed no septic focus. The deep reflexes in the upper extremities were normal : those in the lower limbs were not elicited, even with "reinforcement," whilst the patient was resting in bed, but later, when he was up and taking exercise, were definitely exaggerated, especially the knee jerks. The Wassermann reaction of the blood was negative (one examination).

The vision underwent a slight improvement in the course of ten days, when he saw 6/60 once. When his fundus was last 
examined, in October, secondary optic atrophy was commencing. The tension had remained normal. The patient has now left the district, but when last heard of, in April 1925, had had no painful complications.

Cases in the literature where septic foci in the retina have been traced to disease of the nasal sinuses are, of course, very numerous and there is little to be added to Eversbusch's ${ }^{(2)}$ Monograph, 1903. Fish $^{\left({ }^{3}\right)}$ follows Zeim ${ }^{(6)}$ in associating all cases with venous stasis and thrombosis. Most of Fish's cases had extreme trigeminal pain, whereas the case above reported complained of no pain. Many cases, as for instance that published in 1911 by Hett and Henderson ${ }^{(5)}$ were similar to the above in that no cause could be found on examination.

\section{REFERENCES}

1. Berger, Emile.-Rapports entre les maladies des yeux et celles du nez et des cavitès voisins. Paris, 1892.

2. Eversbusch.-Graefe-Saemisch Handbuch der gesam. Augenheilk., Vol. IX, chap. XVI.

3. Fish, H. M.-Some cases of Uveitis due to Accessory Sinus disease, Amer. Jl. of Ophthal., XXI, 12, p. 353 Dec., 1904.

4. Foster Moore in Medical Ophthalmology, p. 85, quoting Arch. f. Ophthal., Vol. LXXXVI, p. 84, 1913.

5. G. Seccombe Hett and E. Erskine Henderson.-Ophthal. Rev., Vol. XXX, p. 107, London, 1911

6. Zeim.-Berl. klin. Wochenschr., p. 833, 1889.

\section{DIPLOPIA LAMP}

DESIGNED BY

\section{E. Nicholas Hughes, D.O.M.S.}

HONORARY OPHTHALMIC SURGEON, WALLASEY COTTAGE HOSPITAL HONORARY ASSISTANT SURGEON, ST. PAUL'S EYE HOSPITAL, LIVERPOOL

THE method of testing diplopia with a candle flame has several disadvantages. The size of the flame is too small to allow the patient to describe accurately any tilting of the images that may be present. The candle flame illuminates surrounding objects and distracts the patient's attention. The flame moreover is constantly moving in air currents, making it still more difficult for the patient to describe what he sees.

It is often a matter of great difficulty for the surgeon to interpret the patient's description of the double images.

The diplopia lamp has been designed to eliminate the disadvantages of the candle flame, and also to provide the patient with a means with which he can demonstrate to the surgeon the exact position and relation of the true and false image. 